\title{
College Quality and Earnings in the Japanese Labor Market
}

\author{
SSE/EFI Working Paper Series in Economics and Finance No 395
}

August 22, 2000, Revised March 11, 2003

\section{Hiroshi Ono}

\section{Stockholm School of Economics}

\footnotetext{
* Revised version of paper originally presented at the National Bureau of Economic Research Conference, Tokyo, Japan, September 2000. Please direct all correspondences to Hiroshi Ono, Stockholm School of Economics, P.O. Box 6501, S-113 83, Stockholm, Sweden (E-mail: hiroshi.ono@hhs.se). I am grateful to Yukiko Abe, Gary Becker, Anders Bjorklund, Mary Brinton, Marlis Buchmann, Thomas DiPrete, George Farkas, Adam Gamoran, Canice Prendergast, Marcus Rebick, Kazuo Yamaguchi and seminar participants at Stockholm University for comments on an earlier draft of the paper. I also thank the Center for East Asian Studies at the University of Chicago and the American Compensation Association for their generous financial support.
} 


\begin{abstract}
The motivations underlying the pursuit of college prestige in Japan presumes a labor market that rewards workers according to the quality of the college that they attended. Yet, studies that examine the relationship between college quality and earnings in Japan remain few and riddled with shortcomings. This paper examines the returns to college education among Japanese men. Using a 1995 cross-sectional data of Japanese workers, I find that college quality significantly improves earnings. My findings confirm that college quality plays a crucial role in shaping both incentives and earnings in the Japanese labor market. The paper also examines the so-called distinctive features of the Japanese labor market, and confirms the significant impact of tenure and firm-size on earnings, and the similarity in the earnings profiles between blue- and white-collar workers.
\end{abstract}

Keywords: human capital formation, returns to education

JEL Classification: I21, J24, J31, N35 


\section{Introduction}

The pursuit of college prestige in Japan is unparalleled. Acceptance into the top universities is extremely competitive. Students, with generous support from their parents, make considerable investments in their mission to gain entry into the prestigious universities. The motivations underlying such investments can only be explained under a labor market that rewards workers in accordance to the quality of the college that they attended.

The aim of this paper is to examine the effects of college quality on earnings in the Japanese labor market. In contrast to the volume of research that documents the competitive process of college entrance in Japan, research that examines the returns to college quality remains few and riddled with shortcomings. My research attempts to fill this void. Using a unique 1995 cross-sectional dataset, we estimate college quality effects using a properly specified earnings equation that controls for both supply- and demand-side characteristics of the labor market.

The paper is organized as follows. Section 2 discusses the relevant literature on college quality and features of the Japanese labor market that may affect the specification of the earnings function. Section 3 describes the data and variables used in the estimations. Section 4, presents the analysis of the returns from college education and the impact of labor market characteristics using Mincerian regressions. Section 5 summarizes the paper's main findings and discusses directions for further research.

\section{Background}

The effect of college quality on earnings 
In his seminal work, Schooling, Experience and Earnings, Mincer (1974) explains that the explanatory power of the human capital earnings function can be further increased when the quality of schooling can be controlled for. Schooling is an investment that imparts skills, and these skills increase productivity and earnings. But if productivity gains vary depending on the quality of the institution attended, then it is likely that earnings estimates will be biased if we do not control for quality differences.

In comparison to the volume of research that examines the returns to the quantity of schooling, studies focusing on quality effects are relatively few, mainly because of the difficulty in obtaining detailed information about student and institutional characteristics (James et al 1989). Nevertheless, researchers have advanced the schooling quality literature by outlining the definitions and measurement of school quality (Solmon 1975; Welch 1966), incorporating schooling quality into the Mincerian estimation (Behrman and Birdsall 1983; Solmon and Wachtel 1975), and examining the relationship between individual ability, school quality and earnings (Brewer, Eide and Ehrenberg 1999; Dale and Krueger 1999; Griliches and Mason 1972; Kingston and Smart 1990; Solmon and Wachtel 1975).

Studies looking at school quality effects have concentrated on differences in college quality, given that data on quality differences (such as mean SAT scores and per pupil expenditure) are more readily observable at the college level than at the high school level. These theoretical and methodological advances have given rise to a number of empirical studies in the U.S., all of which confirm that college quality 
improves individual earnings or upward mobility. ${ }^{1}$ The U.S. evidence thus supports the claim that it matters where one goes to college, and not just how much college education one receives. The prestige of the college degree has significant economic consequences, and "where one was schooled" is a salient feature of everyday life (Kingston and Lewis 1990).

\section{The Case of Japan}

In Japan, the question of who graduated from where is a national obsession. Articles that feature personnel moves among important persons - whether they be in politics, government or the private sector - will be sure to report the which schools they graduated from. In addition, there are numerous publications that rank the number of politicians, bureaucrats and executives by their graduating institutions on an annual basis. ${ }^{2}$ As Dore (1973) explains, "it is not so much important to get into a university as important to get to the right university." (p.294, emphasis mine).

In Japan, admission into college requires successfully passing the entrance examinations administered by each institution. Examination hell, which refers to the cramming and preparing that the students undertake in order to pass the entrance examinations, is an expression common to all households with college bound children. Unlike in Western societies where factors such as high school performance and extracurricular activities are considered in the admission process, college admission in

\footnotetext{
${ }^{1}$ See Fox (1993), James, et al (1989), Kingston and Smart (1990), Loury and Garman (1995), Morgan and Duncan (1979), Solmon (1975) and Wales (1973) for studies on college quality and earnings, and Ishida, Spilerman and Su (1997), Karabel and McClelland (1987), and Useem and Karabel (1985) for studies relating to college quality and promotions.

${ }^{2}$ See for example publications by Diamond, Kawai Juku, and Toyo Keizai.
} 
Japan is determined almost entirely by the performance in entrance examinations. ${ }^{3}$

Investments undertaken in examination hell are considerable. Some 30 percent

of students spend additional years preparing for these examinations after high school

graduation, often attending specialized college preparatory schools. According to

Sakurai (1997), the supplementary education industry in Japan now grosses one percent

of the country's GDP, and secular trends show that the proportion of household

expenditures spent on supplementary education has grown monotonically in the postwar

period. Bowman (1981) explains:

This sort of supplementary university preparation is familiar in countries in which only a small minority of highly advantaged individuals complete upper-secondary school; Greece and Brazil are examples. But Japan is different, with the large and growing rates of enrollment in higher education. In Japan competition for entry to preferred institutions has reached a frenzy probably matched in no other part of the world (1981: 15).

The motivations underlying examination hell can only be explained under a labor market that rewards workers depending on the quality of the college that they attended: If all workers were rewarded the same regardless of college quality, then there would be no incentive to invest in college quality. Hence there is good reason to suspect significant variation in rewards as a function of college quality.

\footnotetext{
${ }^{3}$ In recent years, Japanese universities have increased the proportion of students admitted through recommendations (suisen nyugaku) and have started to introduce admissions procedures similar to the U.S. where applicants are evaluated on the basis of their high-school performance and activities. However, these proportions are still small. For example, according to the 1997 Obunsha publication, the proportion of applicants accepted through recommendation at Waseda University and Keio University were 8 percent and 3 percent, respectively. For the 1945 to 1991 cohort of applicants covered in the current study, these proportions are even smaller. Hence, we assume in this study that the majority of the students entered universities through the entrance examinations. For current data concerning the number of students admitted through recommendation, see for example:

http://www3.asahi.com/opendoors/gaku/daigaku/index.html (in Japanese).
} 
The competitive nature of the college entrance process in Japan has attracted considerable attention from scholars from various disciplines. However, most studies focus on the process itself (Rohlen 1983; Stevenson and Baker 1992; Tsukada 1991). Studies that examine college quality effects on occupational outcomes are extremely few, and their findings are limited. For example, Ando (1994) uses the 1975 Social Stratification and Mobility survey and categorizes universities into "five arbitrary groups of prestige" (1994: 288) - top national universities, other national and public universities, top private universities, other selective private universities, and other private universities - and cross tabulates these groups with current earnings in four different cohorts. ${ }^{4}$ Based on this categorization, Ando finds very little systematic difference between groups. Using the same data, Ishida groups universities into three categories of prestige - highly selective, selective, and non-selective - and finds that graduates of highly selective and selective institutions have higher income than those of non-selective institutions. ${ }^{5}$

The main reason why research in this field has been limited is that micro-level data including individual information on college quality (or college affiliation) have not been publicly available. Consequently, some researchers have gone to great lengths to

\footnotetext{
4 “Top national universities" include the seven former Imperial Universities - Hokkaido, Tohoku, Tokyo, Nagoya, Kyoto, Osaka, Kyushu - plus Tokyo Institute of Technology, Hitotsubashi, Kobe, Tokyo University of Foreign Studies and Osaka University of Foreign Studies. "Other national and public universities" include national and public universities not included in the "top national universities." "Top private universities" include Waseda and Keio. "Other selective private universities" include Meiji, Hosei, Rikkyo, Chuo, Doshisha, Ritsumeikan, Kansai Gakuin, Jouchi (Sophia), Aoyama, Meiji Gakuin, ICU and Gakushuin. "Other private universities" include private universities not included in the "top" and "other selective private universities."

5 "Highly selective universities" include the seven former Imperial Universities plus Tokyo Institute of Technology, Hitotsubashi, Kobe, Waseda and Keio. "Selective universities" include all other national and public universities, plus the "other selective private universities" from Ando's study (see previous footnote). "Other private universities" include all other private universities.
} 
overcome this obstacle by estimating the rates of return through a series of simulations using aggregate data. These studies typically rely on two different sources of data. The first source of data is occupational outcomes by college. Commonly used data of this form is Daigaku betsu Shushoku Shirabe (occupational outcomes by college) published by Recruit which reports, for example, the distribution of the graduates of college $x$, that entered industry sector $y$, of firm size $z$. The second source is the Basic Wage Survey which reports the basic wages of workers by industry sector and firm size. Rates of return are then estimated using the conditional probability of a given college group entering a certain sector of the labor market. Because of the number of procedures involved, researchers typically pre-select a small sub-sample of colleges or college categories of interest. The results of two representative studies (Iwamura 1996; Yano 1978) conducted under this estimation procedure are reported in Table $1 .^{6}$ Although these estimates are a significant improvement in comparison to earlier simulations that did not account for occupational outcome differences by college affiliation, some cautionary remarks are necessary. ${ }^{7}$

\section{TABLE 1 ABOUT HERE}

\footnotetext{
${ }^{6}$ There are other studies that use a similar method of estimating occupational outcomes by college affiliation, but they are not reported here because they do not report rates of return. For example, Abe (1997) uses the Recruit data to estimate the probability that graduates from colleges that differ in rank enters prestigious (or popular) private sector firms. Higuchi (1994) also uses the Recruit data to examine the distribution of college graduates' employment into firms differing in size as a function of college rank. ${ }^{7}$ Earlier studies of this form were quite limited and primitive. For example, Nobukuni (1977, cited in Iwamura 1996) estimates that national university graduates have the highest rate of return and private university graduates majoring in the sciences have the lowest rate of return. This outcome is nothing more than a reflection of different tuition rates charged at these institutions. It should also be noted that
} 
First, differences in earnings result only from differences in the distribution of employment which may have little do with college quality. ${ }^{8}$ Rates of return are estimated using the conditional probability of employment in a particular sector of the labor market given college affiliation. For example, in Yano's study, Waseda and Keio graduates have higher rates of return because these graduates were more likely to be employed in larger firms than graduates of other private universities. Therefore, if by chance two universities of differing quality have the same employment distribution with respect to firm size, their rates of return will be identical. Second, because the estimations are based on aggregate data, these studies assume that all individuals in the selected reference categories earn the same amount, e.g. all individuals working for firms with over 1000 employees earn the same regardless of the quality of college that they attended. This is another way of saying that controlling for firm size has the same effect as controlling for college quality. Third, since the data do not distinguish between men and women, they assume that gender differences in occupational outcomes are not significant. But there remains a sizeable gender gap with respect to earnings and employment distribution in Japan, and such an assumption undermines the generalization of their results. And fourth, because these estimates were derived through simulations involving different sources of data, we have no way of knowing if the rates of return between colleges are significantly different from each other. The SSM microdata that I use in the current paper allow us to overcome these shortcomings. 
The techniques and methods that I apply will be discussed in detail in Sections 3 and 4.

\section{Features of the Japanese labor market}

Rate of return estimations require specifying an earnings function that captures the essential features of the labor market. We must therefore identify the key determinants of earnings so that they can be properly specified in the empirical analysis. Of considerable importance is accounting for the so-called unique features of the Japanese employment system. In particular, comparative studies of Japanese and U.S. labor markets have established that employer (or demand-side) characteristics play a larger role in determining wages in Japan relative to the U.S. (Kalleberg and Lincoln 1988; Kawashima and Tachibanaki 1986; Rebick 1993). ${ }^{9}$ Neglecting to account for employer characteristics may therefore obscure true earnings. In this section, I briefly discuss four distinctive features of the Japanese labor market which may influence earnings: seniority based wages, permanent employment practices, "white-collarization of blue-collar workers," and demarcation of the labor market by firm size.

(a) Seniority-based wages. A seniority-based wage structure (hereafter seniority) is a system whereby wages rise with tenure (duration of employment with the same employer) and not necessarily with respect to work experience. Although the seniority system is not necessarily unique to Japan, comparative studies have confirmed that the seniority effect is stronger among Japanese employers (Kawashima and Tachibanaki 1986; Mincer and Higuchi 1989). For example, Hashimoto and Raisian

\footnotetext{
${ }^{8}$ Yano controls for firm-size differences but does not control for industry sector.

${ }^{9}$ For example, Rebick reports that human capital measures (education and experience) can explain up to
} 
(1985) find that the tenure-earnings profile of Japanese workers is steeper than that of American workers. Kalleberg and Lincoln (1988) find that wages of Japanese workers are determined primarily by age and seniority, while in the U.S. they are more likely to be conditioned by the occupation. ${ }^{10}$ As Aoki (1988) explains, the persistence of seniority and permanent employment practices are "stylized facts" of the Japanese employment system.

(b) Permanent employment practices. Evidence suggests that interfirm mobility is lower in Japan than in the U.S. (Hashimoto and Raisian 1989; Mincer and Higuchi 1987; Tachibanaki 1984). Hashimoto and Raisian (1985) report that in the aggregate, Japanese male workers have longer tenure and hold fewer jobs throughout their careers than their U.S. counterparts. They also find that years of work experience previous to the current firm tend to penalize earnings growth among Japanese workers, while the reverse holds true for U.S. workers. Kato and Rockel (1992) find a similar pattern of rewards at the executive level. In Japanese corporations, compensation is structured "so as to have managers penalized for job changes, whereas U.S. corporations tend to reward managers for engaging in job hopping" (p.47). They suggest that such incentive structures encourage workers to be committed to the firm. Their findings reinforce the prevailing view that Japanese corporations are apt to engage in longer-term strategies owing to the lower turnover among executives.

(c) "White-collarization of blue-collar workers." The Japanese labor market is characterized by the comparatively weak distinction between blue- and white-collar 
workers. Koike asserts that blue-collar workers in large Japanese establishments often acquire a wide range of skills through frequent job rotation. Unlike their Western counterparts, Japanese blue-collar workers acquire high levels of firm-specific skills through their job experience, much as white-collar workers do. Koike (1988) explains that this "white-collarization of blue-collar workers" obscures the distinction between the two occupational groups. Using aggregate-level data, he shows that the shape of the experience-earnings profiles between blue- and white-collar workers in Japan are remarkably similar, while in Western countries we observe blue-collar earnings profiles that are typically much flatter relative to white-collar workers.

(d) Firm-size differences. Comparative studies have found that labor market demarcation in Japan is more pronounced along lines of firm size rather than along different product markets and industries (Bronfenbrenner and Yasuba 1987; Kalleberg and Lincoln 1988; Kawashima and Tachibanaki 1986; Rebick 1993; Tachibanaki and Ohta 1994). In contrast to large firms, small firms on average pay lower wages for similar types of work and provide fewer fringe benefits. ${ }^{11}$ Yano (1991) explains that in Japan, firm size has an effect on earnings similar to that of educational attainment. ${ }^{12}$ Using estimates of lifetime income, he shows that middle school graduates working in large firms can overtake the earnings of university graduates working in small firms.

and promote job rotation for both blue and white-collar workers. They explain that, "Americans pursue careers within occupations that cut across firms, while the opposite pattern holds in Japan." (p.297).

${ }^{11}$ For example, Bronfenbrenner and Yasuba (1987) find that in 1960, the ratio of mean wages in establishments with 5-29 workers versus establishments with more than 500 workers was .46. In 1980, this ratio was .58. Similarly, Rebick reports that in 1988, the difference in logged average hourly earnings between large (more than 1000) and small firms (less than 100) in Japan was .54 compared to .28 in the U.S. See also, Lincoln and Kalleberg (1985) and Lincoln and McBride (1987) for explanations of firm-size differences in Japan.

${ }^{12}$ See also "Table 10.4: Annual income (in yen) of university and high school graduates, by size of 
Lower educated workers can therefore overcome their earnings deficits by being employed in larger size establishments.

\section{Data and Variables}

The dataset used for the analysis is the 1995 Social Stratification and Mobility National Survey (SSM) which consists of a representative sample of men and women between the ages of 20 and 69 residing in Japan in $1995 .{ }^{13}$ SSM is particularly suited for the present research because it reports the name of the college among respondents who attended college. College quality is measured by the mean scores on entrance examinations administered by each college as reported by Obunsha (see Appendix for description of coding procedure). ${ }^{14}$ By using a clear-cut hierarchical ranking of all schools included in the SSM survey, I avoid pigeonholing schools into a small number of categories. Further, the SSM sample allows us to overcome the unrepresentative nature of previous studies which were limited to only a select group of colleges.

The SSM also includes a self-reported measure of the respondent's grade point average (GPA) in ninth grade. ${ }^{15}$ This feature allows controlling for individual ability differences in addition to college quality. As Griliches and Mason (1972) have argued, it is misleading to assume that college quality and individual ability are substitutable because the two may be complementary: ability may affect earnings independent of college quality. Earnings functions which do not account for one or the other may

company, Japan, 1982" in Ushiogi (1986: 202).

${ }^{13}$ I am grateful to Mary Brinton and the SSM Committee for permission to use the 1995 SSM data.

${ }^{14}$ I am grateful to Hisashi Arai of Obunsha for allowing me access to past issues of their publications.

${ }^{15}$ A caveat here is that self-reported GPA may be subject to measurement error. See for example Kruger 
therefore bias rate of return estimates. By specifying the earnings function using individual ability and college quality, we can overcome the shortcomings of previous studies and derive more accurate rates of return.

The reliability of the SSM earnings data as a representative sample of Japanese male workers has been documented by Yano (1998), who compared the SSM data with actual earnings reported in the Ministry of Labor's publication, Basic Wage Survey. ${ }^{16}$ Based on Mincerian estimation results, Yano shows that the SSM earnings data provide estimates that conform very closely to those of the Basic Wage Survey and suggests that the SSM earnings data are indeed "useful." My estimation results should therefore not be a misrepresentation of male workers in the Japanese labor force.

My empirical analysis is limited in the following ways. First, my analysis is restricted to men. Given the intermittent career mobility patterns of Japanese women, it is difficult to obtain reliable rate of return estimations for women. An accurate analysis of women's returns to college education would require that they be analyzed separately. Second, in order to minimize heterogeneity, I eliminate workers employed in agriculture and the government sector, because the employment practices in these sectors deviate from those in the private sector. ${ }^{17}$ Third, the current sample of college graduates includes four-year university graduates only. Respondents who were enrolled in college at the time of the survey were excluded. Respondents who reported having graduated with Masters or Doctorate degrees were not considered because the SSM asks for the name of the university from which the respondent last graduated, so these 
respondents provided the name of their graduate institutions and not their undergraduate institutions. Since entrance examinations concern the admittance into universities from high school, the missing information was crucial, and I therefore excluded respondents who reported to have graduated with post-baccalaureate degrees. And finally, the current sample excludes respondents who graduated from college under the prewar educational system. Japan's educational system - its curriculum and time spent in formal education - was revamped considerably by the U.S. Occupation. The differential investments in human capital prior to the war may introduce heterogeneity into the empirical analysis. Respondents who graduated college prior to 1953, the year that marks the first cohort under the postwar system, were dropped from the sample. The resulting sample size after accounting for the above conditions is 570 . The sample size remains the same throughout the analysis. Table 2 provides the means, standard deviations, and brief descriptions of the variables used for the estimations. Further descriptions of the variables will be provided in the following section where necessary.

TABLE 2 ABOUT HERE

\section{The rate of return to college education}

This section describes the analysis and results of the rate of return estimations among Japanese male workers in the SSM survey. Rates of return were estimated using

\footnotetext{
${ }^{17}$ For further discussion of government sector employment practices, see Yamaguchi (1983) and Ono (forthcoming).
} 
the Mincerian regression. The standard Mincerian equation takes the following form: ${ }^{18}$

$$
\ln Y=\alpha+\rho s+\beta_{1} x+\beta_{2} x^{2}+\mathbf{X f}+\varepsilon
$$

where $\ln Y$ is the natural logarithm of annual earnings, $s$ is the years of college completed, $x$ is years of work experience, $\mathbf{X}$ is a vector of other variables which may affect earnings, $\varepsilon$ is the error term, and $\alpha, \rho$, and $\beta$ are coefficients to be estimated from the regression. In my analysis, $s$ is coded as the number of years spent in college such that $s=0$ for high school graduates, $s=4$ for college graduates, and $\rho$ measures the rate of return from an additional year of college education. Work experience $(x)$ is coded as the years of actual work experience that accounts for durations of non-employment.

Table 3 reports the results of F-tests conducted to compare models before and after addition of the variables described in Table 2. The effects of individual ability and college quality were assessed separately (Models 20 to 23) in order to estimate the 'true' effects of these variables before controlling for labor market characteristics. I present the highlights from the model comparisons in greater detail in the following pages.

\section{TABLE 3 ABOUT HERE}

College education, experience and tenure effects

\footnotetext{
${ }^{18}$ See Mincer (1974) for assumptions underlying the equation. For studies that evaluate the predictions
} 
The first three columns of Table 4 show the results of the Mincerian regressions examining the effects of college education, experience, and tenure. The model numbers in Table 4 correspond to the model numbers reported in Table 3 . In Model 1, we confirm the strong predictive power of the standard Mincerian variables: Years of college, experience, and experience squared alone explain roughly one-third of the variance in earnings. According to the basic equation (Model 1), the unadjusted (or gross) rate of return from one year of college education is 8.7 percent. The starting salary of high school graduates is estimated to be 2,032,953 yen $\left(=\mathrm{e}^{\alpha=14.525}\right)$, which compares well with the 1,961,700 yen reported in the Basic Wage Survey in 1995.

\section{TABEL 4 ABOUT HERE}

In Model 2, we find that the tenure effect is highly significant and positive, but that adding tenure-squared to Model 2 does not significantly improve the fit of the model (see Table 3). Contrary to the concavity effects of work experience, the tenure effect is linear, suggesting that earnings continue to rise monotonically for workers who remain with the same firm. In Model 4, we find that college education affects earnings primarily through its interactions with experience and tenure. The signs of the coefficients suggest that compared to high school graduates, the experience earnings profile for college graduates is steeper and their returns to tenure are smaller. 


\section{Labor market effects}

The last six columns of Table 4 show the results of Mincerian regressions after controlling for labor market characteristics. In Model 7, we find that the coefficient for the number of previous employers is negative, thereby confirming that Japanese workers who change employers frequently are penalized for their actions. We also confirm the effect of "white-collarization of blue-collar workers" in the Japanese labor market. While white-collar workers earn more than blue-collar workers, we find that adding the variables interacting white-collar and experience, and white-collar and tenure to Model 7 does not improve the fit of the model (see Table 3, Models 9 and 10), i.e., the slopes of the earnings profile with respect to experience and tenure do not significantly differ between blue- and white-collar workers. However, in Model 11, we find that the main effect of the number of previous employers becomes insignificant after we include its interaction term with the white-collar dummy. This finding suggests that the penalty for job changes only applies to white-collar and not blue-collar workers.

We next add the industry dummies, consisting of manufacturing (omitted category), retail, finance and real estate, and services. The results show that the variance in earnings across industries is significant (see Model 12 in Tables 3 and 4). Finally, the firm-size variable was added as the log of the firm-size. The results show a significant improvement in fit (Model 16). The significance of the interaction term between firm-size and tenure in Model 19 indicates that workers in larger firms have 
more to gain from remaining in the same firm. ${ }^{19}$

Effects of individual ability and college characteristics

If earnings are a function of ability and not schooling, then estimations which do not control for ability may overestimate the true rate of return (Griliches and Mason 1972; Hause 1971, 1972). Equation (1) can be modified to account for individual ability $(G)$ where:

$$
\ln Y=\alpha+\rho s+\tau G+\mathbf{X f}+\varepsilon
$$

In earnings comparisons between groups of high school and college graduates, individual ability must be a pre-college measure (or causally prior to college entry) that is available for both educational categories. In my analysis, I use ninth grade GPA as a proxy for individual ability, appropriately selected because ninth grade is the last year of middle school in Japan. ${ }^{20}$ If college education and ability are mere substitutes, years of college education would significantly improve earnings when ability is not included, but its effect would be cancelled out after controlling for ability. On the other hand, if college education and ability are complementary, then the effects of college education will remain even after controlling for ability, suggesting that college education improves earnings, independent of individual ability. Note that under both scenarios,

\footnotetext{
${ }^{19}$ The addition of firm-size interaction with experience to Model 16 also improved predictions, but the tenure * firm-size interaction term was selected here because the improvement in $\mathrm{R}^{2}$ was found to be greater (see Table 3, Models 18 and 19).

${ }^{20}$ In a purely theoretical human capital framework, "ability" is a measure of inherent (or endowed) ability such as IQ. However, since IQ estimates are typically not available in surveys, researchers use some other measure to proxy ability. Among others, see for example Griliches and Mason (1972) who use the Armed Forces Qualification Test from the 1964 CPS sample of World War II veterans and similarly Willis and Rosen (1979) and Wales (1973) who use military test scores from the NBER-ThorndikeHagen survey of 1968-1971.
} 
controlling for ability will always have the effect of depressing the rate of return unless ability and college education are negatively correlated.

Individual ability may affect the earnings of high school and college graduates in different ways. This can be examined by including an interaction term between college education and ability such that:

$$
\ln Y=\alpha+\rho s+\tau G+\varphi s G+\mathbf{X f}+\varepsilon
$$

$\varphi$ is the effect of ability on earnings in addition to the main effect of college education $(\rho)$. For example, $\varphi>0$ means that the premium for higher ability will be larger among college graduates than for high school graduates.

Following Griliches and Mason (1972), equation (2') can be further modified by accounting for college quality differences $Q$ such that: ${ }^{21}$

$$
\ln Y=\alpha+\rho s+\xi Q+\tau G+\varphi s G+\mathbf{X f}+\varepsilon
$$

It should be noted here that college quality is observed only among those respondents who attended college, so $\rho$ cannot be estimated from the above equation. Further, because college quality is entered into the equation linearly, it is a "shift" factor (Behrman and Birdsall 1983; Solmon and Wachtel 1975) which merely shifts earnings independently of schooling. An adjustment can be made by entering college quality as

\footnotetext{
${ }^{21}$ According to Griliches and Mason, the true effect of schooling (which they call $E$ ) must be captured with respect to both quantity and quality of education, and such an effect can be approximated by assuming that $E=s+Q$ (or $Q=E-s$ ). "Quality," therefore, is the discrepancy between $s$ and the true effect of schooling.
} 
an interaction term with college education in the form:

$$
\ln Y=\alpha+\rho s+\omega s Q+\tau G+\varphi s G+\mathbf{X f}+\varepsilon
$$

Since $\partial \ln Y / \partial s=\rho+\omega Q+\tau G$, the rate of return from college education can be obtained with respect to both quantity $(\rho)$ and quality $(\omega)$. Controlling for ability and college quality in the same equation allows us to examine the extent to which college quality proxies ability. In an earlier study using the same dataset (Ono 2001), I find that higher ability individuals are more likely to advance to higher quality colleges. This leads us with the possibility that ability and college quality may be substitutable, i.e. controlling for one variable will cancel out the effect of the other. Past studies have found that ability and quality are positively correlated, but that the effect of quality remains significant even after controlling for ability (Kingston and Smart 1990; Solmon and Wachtel 1975; Wales 1973).

The first three columns of Table 5 shows the results of Mincerian regression which examine the 'true' effects of individual ability and college quality prior to examining labor market characteristics. The model numbers in Table 5 correspond to the model numbers reported in Table 3.

We start with Model 20 which includes ninth-grade GPA while controlling for variables included in Model 2: experience and tenure. We find that the coefficients for both years of college education and ninth-grade GPA remain significant, and the rate of return is depressed from .084 to .069 . The results indicate that college education and individual ability are complementary: High-ability individuals earn more, but attending college increases their earnings independent of individual ability. In Model 21, we 
conduct the same test that controls for the interaction effects of college education with experience and tenure (Model 4 variables). We find that the coefficient for ninth-grade GPA is significant, but that the coefficient for years of college education is not. This is not surprising because we have already established (from Models 4 to 19 in Table 4) that the effect of college education on earnings is manifested mainly through its interactions with experience and tenure. But the positive coefficient for ninth-grade GPA confirms again that college graduates earn more if they have higher ability. On the other hand, the interaction term with college education and ability is found to be statistically insignificant (see Model 22 in Table 4), suggesting that the effect of ability on earnings is not statistically different between high school and college graduates.

\section{TABLE 5 ABOUT HERE}

In Model 23, the interaction term with years of college education and college quality is significant and positive. This finding confirms the significance of college quality on earnings. The coefficient for ninth-grade GPA is also significant, leading us to reject the possibility that ability and college quality are substitutable. Even among individuals with the same ability, earnings are higher if they attended a higher quality college. The results confirm the importance of treating ability and college quality separately in empirical analysis. And finally, Model 24 shows the results of the Mincerian regression that controls for labor market characteristics examined in Model

19 of Table 4. The college quality effect remains significant and positive. The effect of ninth-grade GPA is weakened suggesting that the impact of ability on earnings is 
manifested indirectly vis-à-vis allocating workers into different positions in the labor market.

The 'true' rate of return to college education $(R O R)$ was estimated as a function of college quality $(Q)$. For this purpose, we estimate a regression that only controls for individual-level attributes - in this case, experience, years of college education, and their interactions - but not employer characteristics. As Becker (1993) explains, "the true effect of education on earnings operates primarily indirectly through the effect on knowledge and skills," such that controlling for such measures as occupation and other labor market characteristics "can eliminate the true effect of education on earnings" (p.178, footnote 25). Labor market characteristics are channels through which the effects of education are mediated. Controlling for these characteristics will therefore undercut the true rate of return to education.

\section{FIGURE 1 ABOUT HERE}

Figure 1a shows earnings profiles evaluated at the mean, minimum and maximum values of college quality, and Figure $1 \mathrm{~b}$ shows the rate of return as a function of college quality. The slope of the graph in Figure $1 \mathrm{~b}$ is the marginal effect of college quality. The rate of return ranges from a low of 2.5 percent to a high of 15.6 percent, with a mean of 7.9 percent. The results indicate that an increase in college quality from one standard deviation (about 6.6 points) below the mean to one standard deviation above the mean raises the rate of return to college education from 5.2 to 10.6 percent. The results confirm the significant impact of college quality among Japanese college graduates. 


\section{Summary and discussion}

This paper has examined the returns to college education among Japanese men. The rate of return to one year of college education that does not account for quality differences (i.e. the quantity effect) is found to be 8.7 percent. I further find that college education affects earnings primarily through its interactions with experience and tenure, as college graduates accrue the returns from their education throughout their worklife.

Does college quality affect earnings? The answer is undeniably yes. My estimation results suggest that there is a substantial variation in the rate of return depending on the quality of the college attended, ranging from a low of 2.5 percent to a high of 15.6 percent. Consistent with earlier research, the rate of return from college education is depressed after controlling for individual ability (as proxied by ninth grade GPA), but college quality effects remain significant, suggesting that college quality boosts earnings capacity independent of individual ability.

My results also confirm the distinctive features of the Japanese labor market, mainly the significant effects of tenure and firm-size on earnings, and the similarity in the compensation structures between white- and blue-collar workers. I also find that workers are penalized for job-hopping, but that this penalty applies only for white-collar and not blue-collar workers.

In general, my estimations suggest that college quality effects in Japan are much stronger than previously claimed. As explained in Section 2, studies of college quality in Japan have been limited, mainly because of data restrictions. The drawback of these earlier estimations is that the differences in the rates of return only accounted 
for differences in employment distribution. In particular, it was assumed that all individuals within the same firm size category and/or industry sector earn the same regardless of college quality. My estimation results suggest otherwise. College quality effects persist strongly after controlling for various labor market characteristics, including firm size and industry, suggesting that even within the same employment categories, graduates of high-quality colleges earn significantly more.

The sizeable variation in the rate of return as a function of college quality confirms in part that examination hell and the obsessive pursuit of college quality in Japan is a rational pursuit. Individuals are sufficiently motivated to get into the better colleges because the payoffs from college quality are substantial. Put another way, we may infer that the variance in rewards is great enough to motivate college-bound students to pursue college quality.

International comparisons have consistently shown that the rate of return to college education in Japan is among the lowest in OECD countries (Blöndal, Field and Girouard 2002; Psacharopoulos 1985, 1993). However, such comparisons may mask the true nature of investment motives for college education in Japan. The average rate of return is an important determinant of college advancement, but it is the variance in rewards resulting from college quality that can truly explain the motivations underlying examination hell and the pursuit of college prestige in Japan.

Establishing whether examination hell is a good investment or not requires a cost-benefit analysis which examines benefits net of costs. An example of this approach is illustrated by Ono (1999), and is worthy of further investigation. This area of research can also benefit by examining other rewards that may motivate examination 
hell. For example, anecdotal evidence suggests that graduates from prestigious universities gain access to privileged social networks that improve their social mobility. A social capital approach to study the impact of college quality on social mobility would further our understanding of the incentives underlying examination hell and the quest for college quality.

A key aspect of higher education which I did not discuss in the current paper concerns family background effects on earnings. In studies of stratification and inequality, the positive association between family background and education has been well established. In a previous study (Ono 2001), I confirm that family background plays a decisive role in determining whether individuals advance to college or not in Japan. This leaves us with the possibility that family background may affect earnings vis-à-vis individuals' differential access to higher education. As discussed by Altonji and Dunn (1996), studies that examine whether the returns to education vary systematically with family background remain surprisingly few. Examining this missing link in the study of earnings in Japan warrants a separate detailed investigation.

And finally, the study of earnings inequality in Japan can benefit considerably from datasets that include a larger number of respondents. Unlike the U.S., data access in Japan is still tightly regulated, making it difficult to conduct empirical research. The analysis undertaken in the current paper, for example, can benefit by allowing us to split the sample into different cohorts to examine changes in the rates of return over time, and/or introduce more variables and interaction terms into our estimations. ${ }^{22}$

\footnotetext{
${ }^{22}$ See for example, Björklund and Kjellström (2002) who examine changes in the rate of return to college education across different cohorts in Sweden, and Brewer, Eide and Ehrenberg (1999) who perform
} 


\section{Appendix}

Coding college quality

Obunsha, a publishing company located in Tokyo, tabulates and publishes results of entrance examinations of Japanese colleges on an annual basis. Their annual publication, Keisetsu Jidai, is the Japanese equivalent of the Barron's Guide to American Colleges and ranks university departments based on results from the examinations administered in the previous year. Test scores are standardized across different universities and range from 30 to 80 ( 80 being the highest).

The SSM dataset is a cross-sectional survey where the respondents' ages range from twenty to seventy. In terms of the entry year into college, these years range from 1945 to 1992 . In the coding process, I used the test scores from the 1966, 1972, 1977, 1982, 1986, 1992 issues of Keisetsu Jidai because there were small fluctuations in the scores of the individual schools over time (see Ishida, Spilerman and $\mathrm{Su}$ [1997] for a similar coding procedure using Obunsha data). I used scores from these respective issues depending upon individuals' entry year. For example, if an individual entered college in 1973, I used the 1972 scores. Because 1966 was the first year in which Obunsha began tabulating examination scores, individuals who entered college prior to 1966 were coded using the 1966 scores as an approximation.

\section{Bibliography}

Abe, Yukiko. 1997. "Shushoku-shijo ni okeru daigaku no meigara koka" (University brand name effects in labor markets). In Hiroyuki Chuma and Terukazu Suruga, eds. Koyo Kanko no Henka to Josei Rodo (Changing Employment Practices and Female Labor Force). Tokyo: University of Tokyo Press. Pp.151-167.

Altonji, Joseph G. and Thomas A. Dunn. 1996. "The Effects of Family Characteristics on the Return to Education." Review of Economics and Statistics 78: 692-704.

Ando, Bunshiro. 1994 (reprint of 1974 edition). "Gakureki shakai kasetsu no kento" (Examining the educational credentialism hypothesis). In Kenichi Tominaga, ed., Nihon no Kaiso Kozo. Tokyo: University of Tokyo Press, pp. 275-292.

Aoki, Masahiko. 1988. Information, Incentives, and Bargaining in the Japanese Economy. Cambridge: Cambridge University Press.

Becker, Gary S. 1993. Human Capital. Chicago: University of Chicago Press.

Behrman, Jere R., and Nancy Birdsall. 1983. "The Quality of Schooling: Quantity Alone is Misleading." American Economic Review, Vol. 73, No. 5 (December), pp. 928-946.

Björklund, Anders and Christian Kjellström. 2002. "Estimating the Return to Investment in Education: How Useful Is the Standard Mincer Equation?" Economics of Education Review 21: 195-210.

Blinder, Alan S. 1976. “On Dogmatism in Human Capital Theory.” Journal of Human Resources 11: 822.

Bowman, Mary Jean. 1981. Educational Choice and Labor Markets in Japan. Chicago: University of

similar analysis in the U.S. that accounts for college quality differences. 
Chicago Press.

Brewer, Dominic J., Eric R. Eide, and Ronald G. Ehrenberg. 1999. "Does It Pay to Attend an Elite Private College? Cross-cohort Evidence on the Effects of College Type on Earnings." Journal of Human Resources 34: 104-123.

Bronfenbrenner, Martin, and Yasukichi Yasuba. 1987. "Economic Welfare.” In Kozo Yamamura and Yasukichi Yasuba, eds. The Political Economy of Japan, Volume 1: The Domestic Transformation. Stanford: Stanford University Press, pp. 93-136.

Cooper, Samuel T. and Elchanan Cohn. 1997. "Internal Rates of Return to College Education in the United States by Sex and Race." Journal of Education Finance 23: 101-133.

Dale, Stacy Berg, and Alan B. Krueger. 1999. "Estimating the Payoff to Attending a More Selective College: An Application of Selection on Observables and Unobservables." Paper presented at the Workshop in Applications of Economics, University of Chicago, February 22, 1999.

Dore, Ronald. 1973. British Factory - Japanese Factory: The Origins of National Diversity in Industrial Relations. Berkeley: University of California Press.

Fox, Marc. 1993. "Is It a Good Investment to Attend an Elite Private College?" Economics of Education Review 12:137-151.

Griliches, Zvi, and William M. Mason. 1972. "Education, Income, and Ability." Journal of Political Economy, Vol. 80, No. 3, Part 2 (May-June), pp. S74-S103.

Hashimoto, Masanori, and John Raisian. 1985. "Employment Tenure and Earnings Profiles in Japan and the United States." American Economic Review, Vol. 75, No.4 (September), pp. 721-735.

1989. "Investments in Employer-Employee Attachments by Japanese and U.S. Workers in Firms of Varying Size." Journal of the Japanese and International Economies 3:31-48.

Hause, John C. 1971. "Ability and Schooling as Determinants of Lifetime Earnings or If You're So Smart, Why Aren't You Rich?” American Economic Review, Vol. 61, No. 2, Papers and Proceedings of the Eighty-Third Annual Meeting of the American Economic Association, pp. 289-298.

. 1972. "Earnings Profile: Ability and Schooling." Journal of Political Economy, Vol. 80, No. 3, Part 2 (May-June), pp. S108-S138.

Heckman, James J., Lance J. Lochner, and Petra E. Todd. 2001. "Fifty Years of Mincer Earnings Regressions.” Manuscript. University of Chicago.

Higuchi, Yoshio. 1994. "Daigaku kyouiku to shotoku bunpai." (College education and income distribution). In Tsuneo Ishikawa, ed. Nihon no Shotoku to Tomi no Bunpai (Distribution of Income and Wealth in Japan). Tokyo: University of Tokyo Press. Pp.245-278.

Ishida, Hiroshi. 1993. Social Mobility in Contemporary Japan. Stanford: Stanford University Press.

Ishida, Hiroshi, Seymour Spilerman, and Kuo-Hsien Su. 1997. "Educational Credentials and Promotion Chances in Japanese and American Organizations." American Sociological Review, Vol. 62, No. 6 (December), pp. 866-882.

Iwamura, Michie. 1996. "Koto-kyouiku no shiteki shuekiritsu" (Private rate of return to higher education). Kyouiku Shakaigaku Kenkyu, No. 58, pp. 5-28. 
James, Estelle, Nabeel Alsalam, Joseph C. Conaty, and Duc-Le To. 1989. "College Quality and Future Earnings: Where Should You Send Your Child to College?" American Economic Review, Vol. 79, No. 2, Papers and Proceedings of the Hundred and First Annual Meeting of the American Economic Association, pp. 247-252.

Kalleberg, Arne L., and James R. Lincoln. 1988. "The Structure of Earnings Inequality in the United States and Japan." American Journal of Sociology, Vol. 94, Supplement, pp. S121-S153.

Karabel, Jerome, and Katherine McClelland. 1987. "Occupational Advantage and the Impact of College Rank on Labor Market Outcomes.” Sociological Inquiry, Vol. 57, pp. 323-347.

Kato, Takao, and Mark Rockel. 1992. "Experiences, Credentials, and Compensation in the Japanese and U.S. Managerial Labor Markets: Evidence from New Micro Data." Journal of the Japanese and International Economies, Vol. 6, pp. 30-51.

Kawashima, Yoko, and Toshiaki Tachibanaki. 1986. "The Effect of Discrimination and of Industry Segmentation on Japanese Wage Differentials in Relation to Education." International Journal of Industrial Organization, Vol. 4, pp. 43-68.

Kingston, Paul William, and Lionel S. Lewis. 1990. "Introduction: Studying Elite Schools in America." In Paul William Kingston and Lionel S. Lewis, eds. The High-Status Track: Studies of Elite Schools and Stratification. Albany: State University of New York Press, pp. xi-xxxiv.

1990. "Undergraduates at Elite Institutions: The Best, the Brightest, and the Richest." In Paul William Kingston and Lionel S. Lewis, eds. The High-Status Track: Studies of Elite Schools and Stratification. Albany: State University of New York Press, pp. 105-120.

Kingston, Paul William, and John C. Smart. 1990. "The Economic Pay-Off of Prestigious Colleges." In Paul William Kingston and Lionel S. Lewis, eds. The High-Status Track: Studies of Elite Schools and Stratification. Albany: State University of New York Press, pp. 147- 174.

Koike, Kazuo. 1983. "Internal Labor Markets: Workers in Large Firms." In Taishiro Shirai, ed, Contemporary Industrial Relations in Japan. Madison: University of Wisconsin Press, pp. 2961.

1987. "Human Resource Development and Labor-Management Relations." In Kozo Yamamura and Yasukichi Yasuba, eds. The Political Economy of Japan, Volume 1: The Domestic Transformation. Stanford: Stanford University Press, pp. 289-330.

1988. Understanding Industrial Relations in Modern Japan. New York: St. Martin’s Press.

Kruger, Justin and David Dunning. 1999. "Unskilled and Unaware of It: How Difficulties in Recognizing One's Own Incompetence Leads to Inflated Self-Assessments." Journal of Personality and Social Psychology 77: 1121-1134.

Lincoln, James R., and Arne L. Kalleberg. 1985. "Work Organization and Workforce Commitment: A Study of Plants and Employees in the U.S. and Japan." American Sociological Review, Vol. 50, No. 6, pp. $738-760$.

Lincoln, James R., and Kerry McBride. 1987. “Japanese Industrial Organization in Comparative Perspective.” Annual Review of Sociology, Vol. 13, pp. 289-312.

Loury, Linda Datcher, and David Garman. 1995. "College Selectivity and Earnings." Journal of Labor Economics, Vol. 13, No. 2, pp. 289-308. 
Maxwell, Nan L. and Jane S. Lopus. 1994. "The Lake Wobegon Effect in Student Self-Reported Data." American Economic Review 84: 201-205.

Mincer, Jacob. 1974. Schooling, Experience, and Earnings. New York: Columbia University Press.

Mincer, Jacob, and Yoshio Higuchi. 1987. "Wage Structures and Labor Turnover in the U.S. and in Japan.” NBER Working Paper, No. 2306.

Morgan, James N., and Greg J. Duncan. 1979. "College Quality and Earnings.” Research in Human Capital and Development, Vol. 1, pp. 103-21.

OECD. 2002. Education at a Glance: OECD Indicators 2002. Paris: OECD.

Ono, Hiroshi. 1999. "Does Examination Hell Pay Off? The Cost-benefit Analysis of University Education in Japan." Paper presented at the NBER Conference in Tokyo, December 1999.

2001. "Who Goes to College? Features of Institutional Tracking in Japanese Higher Education." American Journal of Education 109: 161-195.

. "Training the Nation's Elite: National-Private Sector Differences in Japanese University Education." In AnneBert Dijkstra, Jaap Dronkers, Tom Hoffer and Jules Peschar, eds. Forthcoming in Public-Private Sector Differences in Education.

Psacharopoulos, George. 1985. "Returns to Education: A Further International Update and Implications." Journal of Human Resources 20: 583-604.

1993. "Returns to Investment in Education: A Global Update." World Bank Policy Research Working Paper No.WPS1067.

Rebick, Marcus E. 1993. "The Persistence of Firm-Size Differentials and Labor Market Segmentation in Japan." Journal of Japanese and International Economies, Vol. 7, pp. 132-156.

Rohlen, Thomas P. 1983. Japan's High Schools. Berkeley: University of California Press.

Rosenbaum, James E., and Takehiko Kariya. 1989. "From High School to Work: Market and Institutional Mechanisms in Japan." American Journal of Sociology, Vol. 94, No. 6 (May), pp. $1334-1365$.

Sakurai, Hideki. 1997. “Japan’s Changing Education Market.” NRI Quarterly, Vol. 6, No. 3, pp. 48-69.

Solmon, Lewis C. 1975. "The Definition of College Quality and Its Impact on Earnings." Explorations in Economic Research, Vol. 2, pp. 537-587.

Solmon, Lewis C., and Paul Wachtel. 1975. "The Effects on Income of Type of College Attended." Sociology of Education, Vol. 48, No. 1 (Winter), pp. 75-90.

Stevenson, David Lee and David P. Baker. 1992. "Shadow Education and Allocation in Formal Schooling: Transition to University in Japan." American Journal of Sociology 97: 1639-1657.

Tachibanaki, Toshiaki. 1984. "Labor Mobility and Job Tenure." In Masahiko Aoki, ed., The Economic Analysis of the Japanese Firm. Amsterdam: Elsevier Science Publishers, pp. 77-102.

Tachibanaki, Toshiaki and Souichi Ohta. 1994. "Wage Differentials by Industy and the Size of Firm, and Labour Market in Japan." In Toshiaki Tachibanaki, ed. Labour Market and Economic 
Performance: Europe, Japan and the USA. New York: St. Martin's Press.

Tsukada, Mamoru. 1991. Yobiko Life: A Study of the Legitimation Process of Social Stratification in Japan. Berkeley: University of California Press.

Useem, Michael and Jerome Karabel. 1990. "Pathways to Top Corporate Management." In P. W. Kingston and L. S. Lewis, eds. High-Status Track: Studies of Elite Schools and Stratification. Albany: State University of New York Press, pp. 175-207.

Ushiogi, Morikazu. 1986. "Transition from High School to Work: The Japanese Case.” In W. K. Cummings, E. R. Beauchamp, S. Ichikawa, V. N. Kobayashi, and M. Ushiogi, eds. Educational Policies in Crisis: Japanese and American Perspectives. New York: Praeger, pp. 197-209.

Wales, Terence J. 1973. "The Effect of College Quality on Earnings Results from the NBER-Thorndike Data." Journal of Human Resources, Vol. 8, No. 3, pp. 306-315.

Welch, Finis. 1966. "Measurement of the Quality of Schooling." American Economic Review, Vol. 56, No. 3 (June), pp. 379-392.

Willis, Robert J. and Sherwin Rosen. 1979. "Education and Self-Selection.” Journal of Political Economy 87:S7-S36.

Yamaguchi, Koichiro. 1983. "Civil Servants: The Public Sector.” In Taishiro Shirai, ed., Contemporary Industrial Relations in Japan. Madison: University of Wisconsin Press, pp. 295-311.

Yano, Masakazu. 1978. "Kyouiku no toushi shuueki to shigen haibun" (Rates of return from education and resource allocation). In Shogo Ichikawa, ed., Allocation of Educational Resources in Japan. Tokyo: National Institute for Educational Research, pp. 103-145.

1991. Shiken no Jidai no Shuen (End of the examination era). Tokyo: Yushindo.

1998. "Shotoku kansu no keisoku kara mita kyouiku to shokugyo" (Earnings function approach to the relation between education and occupation). In Takehiko Kariya, ed., The 1995 SSM Research Series, Volume 11. Tokyo: 1995 SSM Research Committee, pp. 105-118. 
Table 1 Rate of return estimates reported in previous $\operatorname{studies}^{1}(\%)$

\begin{tabular}{|c|c|}
\hline Universities & $\%$ \\
\hline \multicolumn{2}{|l|}{ Private rates of return (Yano 1978) } \\
\hline National universities - total & 9.0 \\
\hline Imperial universities $^{2}$ & 9.5 \\
\hline Other old prestigious universities & 9.1 \\
\hline New universities & 8.7 \\
\hline Private universities - total & 7.5 \\
\hline Waseda and Keio & 8.4 \\
\hline Old private universities & 7.7 \\
\hline New private universities & 6.9 \\
\hline \multicolumn{2}{|l|}{ Internal rates of return (Iwamura 1996) ${ }^{3}$} \\
\hline \multicolumn{2}{|l|}{ Top national universities } \\
\hline Hitotsubashi & 10.5 \\
\hline Yokohama & 9.8 \\
\hline Chiba & 9.4 \\
\hline \multicolumn{2}{|l|}{ Top private universities } \\
\hline Keio & 9.9 \\
\hline Rikkyo & 9.0 \\
\hline Aoyama & 9.1 \\
\hline Gakushuin & 9.2 \\
\hline Seijou & 8.3 \\
\hline \multicolumn{2}{|l|}{ Other private universities } \\
\hline Komazawa & 8.1 \\
\hline Musashi & 8.3 \\
\hline
\end{tabular}

Estimates reported here are for social science majors in Yano's study and economics majors in Iwamura's study.

2 "Imperial universities" include Hokkaido, Tohoku, Tokyo, Nagoya, Kyoto, Osaka and Kyushu Universities, "other old prestigious universities" include Tokyo Institute of Technology, Hitotsubashi, Kobe, Tokyo Foreign Languages and Osaka Foreign Languages Universities, "new universities" include other national universities not included in the first two categories, "old private universities" include Meiji, Hosei, Rikkyo, Chuo, Doshisha, Ritsumeikan, Kansai Gakuin, Jochi (Sophia), Aoyama, Meiji Gakuin, ICU and Gakushuin, and "new private universities" include other private universities not included in the first two categories of private universities.

${ }^{3}$ Results of the Iwamura study reported here were selected from her full study which included a total of 33 university departments. 
Table 2 Means and standard deviations of variables used for estimations

\begin{tabular}{lrr}
\hline \hline \multicolumn{1}{c}{ Variables } & \multicolumn{1}{c}{ Mean } & \multicolumn{1}{c}{ S.D. } \\
\hline Logged annual earnings (yen) & 15.46 & 0.54 \\
Years of college education & 1.30 & 1.87 \\
Experience & 20.83 & 11.35 \\
Tenure (duration of employment at current firm) & 14.43 & 10.95 \\
Number of previous employers & 2.12 & 1.34 \\
White-collar occupation dummy & 0.59 & 0.49 \\
Industry = Manufacturing & 0.49 & 0.50 \\
Industry = Retail & 0.23 & 0.42 \\
Industry = Finance and real estate & 0.06 & 0.24 \\
Industry = Services & 0.21 & 0.41 \\
Logged firm size & 4.26 & 2.23 \\
Grade point average (GPA) in ninth grade & 3.26 & 1.09 \\
College quality (college graduates only) & 51.34 & 6.68 \\
Sample size $(N)=570$ & & \\
\hline \hline
\end{tabular}


Table 3 Model comparisons for Mincerian regression estimations

\begin{tabular}{|c|c|c|c|c|c|c|c|}
\hline Model & Variables & df & $\mathrm{R}^{2}$ & & \multicolumn{3}{|c|}{ F prob } \\
\hline \multicolumn{8}{|c|}{ College education, experience and tenure effects } \\
\hline 1 & Years of college, experience, experience squared & 3 & 0.339 & & - & & \\
\hline 2 & Model $1+$ tenure & 4 & 0.361 & vs & 1 & 0.000 & $* *$ \\
\hline 3 & Model $2+$ tenure squared & 5 & 0.361 & vs & 2 & 0.578 & \\
\hline 4 & $\begin{array}{l}\text { Model } 2+\text { years of college * experience, years of college * } \\
\text { experience squared, years of college * tenure }\end{array}$ & 6 & 0.376 & vs & 2 & 0.004 & $* *$ \\
\hline \multicolumn{8}{|c|}{ Labor market effects } \\
\hline 5 & Model $4+$ number of previous employers & 8 & 0.390 & vs & 4 & 0.000 & ** \\
\hline 6 & Model $5+$ years of college $*$ number of previous employers & 9 & 0.393 & vs & 5 & 0.081 & \\
\hline 7 & Model $5+$ white-collar & 9 & 0.406 & vs & 5 & 0.000 & $* *$ \\
\hline 8 & Model $7+$ years of college $*$ white-collar & 10 & 0.408 & vs & 7 & 0.188 & \\
\hline 9 & Model $7+$ white-collar $*$ experience & 10 & 0.406 & vs & 7 & 0.999 & \\
\hline 10 & Model $7+$ white-collar $*$ tenure & 10 & 0.406 & vs & 7 & 0.974 & \\
\hline 11 & Model $7+$ number of previous employers $*$ white-collar & 10 & 0.418 & vs & 7 & 0.001 & $* *$ \\
\hline 12 & Model $11+$ industry & 13 & 0.435 & vs & 11 & 0.001 & ** \\
\hline 13 & Model $12+$ years of college $*$ industry & 16 & 0.436 & vs & 12 & 0.743 & \\
\hline 14 & Model $12+$ experience $*$ industry & 16 & 0.442 & vs & 12 & 0.075 & \\
\hline 15 & Model $12+$ tenure $*$ industry & 16 & 0.441 & vs & 12 & 0.085 & \\
\hline 16 & Model $12+\log$ firm-size & 14 & 0.442 & vs & 12 & 0.009 & $* *$ \\
\hline 17 & Model $16+$ years of college $*$ log firm-size & 15 & 0.442 & vs & 16 & 0.561 & \\
\hline 18 & Model $16+$ experience $* \log$ firm-size & 15 & 0.447 & vs & 16 & 0.018 & $*$ \\
\hline 19 & Model $16+$ tenure $* \log$ firm-size & 15 & 0.459 & vs & 16 & 0.000 & $* *$ \\
\hline \multicolumn{8}{|c|}{ Individual ability (GPA) and college quality } \\
\hline 20 & Model $2+$ ninth grade GPA & 5 & 0.373 & vs & 2 & 0.001 & $* *$ \\
\hline 21 & Model $4+$ ninth grade GPA & 8 & 0.388 & vs & 4 & 0.001 & $* *$ \\
\hline 22 & Model $21+$ years of college $*$ ninth grade GPA & 9 & 0.388 & vs & 21 & 0.868 & \\
\hline 23 & Model $21+$ years of college $*$ college quality & 9 & 0.404 & vs & 21 & 0.000 & $* *$ \\
\hline \multicolumn{8}{|c|}{ Labor market effects + individual ability $(G P A)$ and college quality } \\
\hline 24 & $\begin{array}{l}\text { Model } 19+\text { ninth grade GPA, years of college } \\
* \text { college quality }\end{array}$ & 17 & 0.474 & vs & 19 & 0.000 & $* *$ \\
\hline
\end{tabular}

$* p<.05, * * p<.01$ 
Table 4 Mincerian regression results

\begin{tabular}{|c|c|c|c|c|c|c|c|c|}
\hline & 1 & 2 & 4 & 7 & 11 & 12 & 16 & 19 \\
\hline Years of college & $\begin{array}{l}0.087 * * \\
(0.010)\end{array}$ & $\begin{array}{l}0.084 * * \\
(0.010)\end{array}$ & $\begin{array}{r}0.017 \\
(0.029)\end{array}$ & $\begin{aligned}-0.014 \\
(0.029)\end{aligned}$ & $\begin{array}{r}-0.030 \\
(0.029)\end{array}$ & $\begin{array}{r}-0.038 \\
(0.029)\end{array}$ & $\begin{array}{r}-0.038 \\
(0.029)\end{array}$ & $\begin{array}{r}-0.023 \\
(0.029)\end{array}$ \\
\hline Experience & $\begin{array}{l}0.071^{* *} \\
(0.006)\end{array}$ & $\begin{array}{l}0.061 * * \\
(0.007)\end{array}$ & $\begin{array}{l}0.046^{* *} \\
(0.008)\end{array}$ & $\begin{array}{l}0.052 * * \\
(0.008)\end{array}$ & $\begin{array}{l}0.050^{* *} \\
(0.008)\end{array}$ & $\begin{array}{l}0.049^{* *} \\
(0.008)\end{array}$ & $\begin{array}{l}0.050^{* *} \\
(0.008)\end{array}$ & $\begin{array}{l}0.048^{* *} \\
(0.008)\end{array}$ \\
\hline Experience squared & $\begin{array}{l}-1.16 \times 10^{-3} * * \\
\left(1.49 \times 10^{-4}\right)\end{array}$ & $\begin{array}{l}-1.08 \times 10^{-3} * * \\
\left(1.48 \times 10^{-4}\right)\end{array}$ & $\begin{array}{l}-8.10 \times 10^{-4} * * \\
\left(1.79 \times 10^{-4}\right)\end{array}$ & $\begin{array}{l}-8.53 \times 10^{-4} * * \\
\left(1.76 \times 10^{-4}\right)\end{array}$ & $\begin{array}{l}-8.21 \times 10^{-4} * * \\
\left(1.75 \times 10^{-4}\right)\end{array}$ & $\begin{array}{l}-8.27 \times 10^{-4} * * \\
\left(1.75 \times 10^{-4}\right)\end{array}$ & $\begin{array}{l}-8.36 \times 10^{-4} * * \\
\left(1.74 \times 10^{-4}\right)\end{array}$ & $\begin{array}{l}-7.82 \times 10^{-4} * * \\
\left(1.72 \times 10^{-4}\right)\end{array}$ \\
\hline Tenure & & $\begin{array}{l}9.98 \times 10^{-3} * * \\
\left(2.30 \times 10^{-3}\right)\end{array}$ & $\begin{array}{l}1.32 \times 10^{-2} * * \\
\left(2.61 \times 10^{-3}\right)\end{array}$ & $\begin{array}{l}7.01 \times 10^{-3} * \\
\left(3.08 \times 10^{-3}\right)\end{array}$ & $\begin{array}{l}7.58 \times 10^{-3} * \\
\left(3.05 \times 10^{-3}\right)\end{array}$ & $\begin{array}{l}8.00 \times 10^{-3} * * \\
\left(3.04 \times 10^{-3}\right)\end{array}$ & $\begin{array}{l}7.75 \times 10^{-3} * \\
\left(3.03 \times 10^{-3}\right)\end{array}$ & $\begin{array}{l}-4.14 \times 10^{-3} \\
\left(4.14 \times 10^{-3}\right)\end{array}$ \\
\hline Years of college * experience & & & $\begin{array}{l}0.012 * * \\
(0.004)\end{array}$ & $\begin{array}{l}0.013 * * \\
(0.004)\end{array}$ & $\begin{array}{l}0.015 * * \\
(0.004)\end{array}$ & $\begin{array}{l}0.015 * * \\
(0.004)\end{array}$ & $\begin{array}{l}0.014 * * \\
(0.004)\end{array}$ & $\begin{array}{l}0.013 * * \\
(0.004)\end{array}$ \\
\hline $\begin{array}{l}\text { Years of college * experience } \\
\text { squared }\end{array}$ & & & $\begin{array}{l}-2.38 \times 10^{-4} * * \\
\left(8.41 \times 10^{-5}\right)\end{array}$ & $\begin{array}{l}-2.53 \times 10^{-4} * * \\
\left(8.22 \times 10^{-5}\right)\end{array}$ & $\begin{array}{l}-2.83 \times 10^{-4} * * \\
\left(8.20 \times 10^{-5}\right)\end{array}$ & $\begin{array}{l}-2.84 \times 10^{-4} * * \\
\left(8.10 \times 10^{-5}\right)\end{array}$ & $\begin{array}{l}-2.72 \times 10^{-4} * * \\
\left(8.07 \times 10^{-5}\right)\end{array}$ & $\begin{array}{l}-2.50 \times 10^{-4} * * \\
\left(7.97 \times 10^{-5}\right)\end{array}$ \\
\hline Years of college $*$ tenure & & & $\begin{array}{l}-3.67 \times 10^{-3} * * \\
\left(1.35 \times 10^{-3}\right)\end{array}$ & $\begin{array}{l}-3.14 \times 10^{-3} * \\
\left(1.33 \times 10^{-3}\right)\end{array}$ & $\begin{array}{l}-4.27 \times 10^{-3} * * \\
\left(1.36 \times 10^{-3}\right)\end{array}$ & $\begin{array}{l}-3.93 \times 10^{-3} * * \\
\left(1.35 \times 10^{-3}\right)\end{array}$ & $\begin{array}{l}-3.89 \times 10^{-3} * * \\
\left(1.34 \times 10^{-3}\right)\end{array}$ & $\begin{array}{l}-3.88 \times 10^{-3} * * \\
\left(1.32 \times 10^{-3}\right)\end{array}$ \\
\hline Number of previous employers & & & & $\begin{array}{l}-0.053^{* *} \\
(0.017)\end{array}$ & $\begin{array}{r}-0.017 \\
(0.020)\end{array}$ & $\begin{array}{r}-0.014 \\
(0.020)\end{array}$ & $\begin{array}{r}-0.012 \\
(0.020)\end{array}$ & $\begin{array}{r}-0.015 \\
(0.019)\end{array}$ \\
\hline White-collar dummy & & & & $\begin{array}{l}0.158^{* *} \\
(0.040)\end{array}$ & $\begin{array}{l}0.357^{* *} \\
(0.072)\end{array}$ & $\begin{array}{l}0.352 * * \\
(0.072)\end{array}$ & $\begin{array}{l}0.304 * * \\
(0.074)\end{array}$ & $\begin{array}{l}0.284 * * \\
(0.073)\end{array}$ \\
\hline $\begin{array}{l}\text { Number of previous employers } \\
* \text { white-collar dummy }\end{array}$ & & & & & $\begin{array}{l}-0.092 * * \\
(0.028)\end{array}$ & $\begin{array}{l}-0.081 * * \\
(0.028)\end{array}$ & $\begin{array}{l}-0.068^{*} \\
(0.028)\end{array}$ & $\begin{array}{l}-0.067 * \\
(0.028)\end{array}$ \\
\hline Industry $=$ Retail & & & & & & $\begin{array}{l}-0.111 * \\
(0.047)\end{array}$ & $\begin{array}{r}-0.077 \\
(0.049)\end{array}$ & $\begin{array}{r}-0.066 \\
(0.048)\end{array}$ \\
\hline Industry $=$ Finance and real estate & & & & & & $\begin{array}{r}0.147 \\
(0.077)\end{array}$ & $\begin{array}{r}0.141 \\
(0.077)\end{array}$ & $\begin{array}{r}0.146 \\
(0.076)\end{array}$ \\
\hline Industry $=$ Services & & & & & & $\begin{array}{r}0.069 \\
(0.048)\end{array}$ & $\begin{array}{r}0.084 \\
(0.048)\end{array}$ & $\begin{array}{r}0.083 \\
(0.047)\end{array}$ \\
\hline Log firm-size & & & & & & & $\begin{array}{l}0.023^{* *} \\
(0.009)\end{array}$ & $\begin{array}{r}-0.022 \\
(0.014)\end{array}$ \\
\hline Tenure $* \log$ firm-size & & & & & & & & $\begin{array}{l}2.89 \times 10^{-3} * * \\
\left(6.96 \times 10^{-4}\right)\end{array}$ \\
\hline Constant & $\begin{array}{l}14.525^{* *} \\
(0.062)\end{array}$ & $\begin{array}{l}14.548^{* *} \\
(0.061)\end{array}$ & $\begin{array}{l}14.652 * * \\
(0.077)\end{array}$ & $\begin{array}{l}14.696^{* *} \\
(0.081)\end{array}$ & $\begin{array}{l}14.629 * * \\
(0.083)\end{array}$ & $\begin{array}{l}14.638 * * \\
(0.085)\end{array}$ & $\begin{array}{l}14.534 * * \\
(0.093)\end{array}$ & $\begin{array}{l}14.737 * * \\
(0.104)\end{array}$ \\
\hline $\mathrm{R}^{2}$ & 0.339 & 0.361 & 0.376 & 0.406 & 0.418 & 0.435 & 0.442 & 0.459 \\
\hline
\end{tabular}

$* p<.05, * * p<.01$. Standard errors reported in parenthesis.

${ }^{1}$ Model numbers correspond to Model numbers in Table 3. 
Table 5 Mincerian regression results ${ }^{1}$

\begin{tabular}{|c|c|c|c|c|c|}
\hline & 20 & 21 & 23 & 24 & $\begin{array}{c}\text { Estimation } \\
\text { equation }\end{array}$ \\
\hline Years of college & $\begin{array}{l}0.069^{* *} \\
(0.011)\end{array}$ & $\begin{array}{r}0.006 \\
(0.029)\end{array}$ & $\begin{array}{l}-0.213^{* *} \\
(0.063)\end{array}$ & $\begin{array}{l}-0.214 * * \\
(0.060)\end{array}$ & $\begin{array}{l}-0.205^{* *} \\
(0.064)\end{array}$ \\
\hline Ninth grade GPA & $\begin{array}{l}0.060^{* * *} \\
(0.018)\end{array}$ & $\begin{array}{l}0.060 * * \\
(0.018)\end{array}$ & $\begin{array}{c}0.046^{*} \\
(0.018)\end{array}$ & $\begin{array}{r}0.021 \\
(0.018)\end{array}$ & $\begin{array}{l}0.048 * * \\
(0.018)\end{array}$ \\
\hline $\begin{array}{c}\text { Years of college * } \\
\text { College quality }\end{array}$ & & & $\begin{array}{l}\text { 4.13E-03** } \\
(1.06 \mathrm{E}-03)\end{array}$ & $\begin{array}{l}3.57 \mathrm{E}-03 * * \\
(1.01 \mathrm{E}-03)\end{array}$ & $\begin{array}{l}4.11 \mathrm{E}-03 * * \\
(1.08 \mathrm{E}-03)\end{array}$ \\
\hline Control variables & Model 2 & Model 4 & Model 4 & Model 19 & $\begin{array}{l}\text { Years of } \\
\text { college, } \\
\text { experience } \\
\text { and their } \\
\text { interactions }\end{array}$ \\
\hline $\mathrm{R}^{2}$ & 0.373 & 0.388 & 0.404 & 0.474 & 0.376 \\
\hline
\end{tabular}

$* p<.05, * * p<.01$. Standard errors reported in parenthesis.

${ }^{1}$ Model numbers correspond to Model numbers in Table 3. 


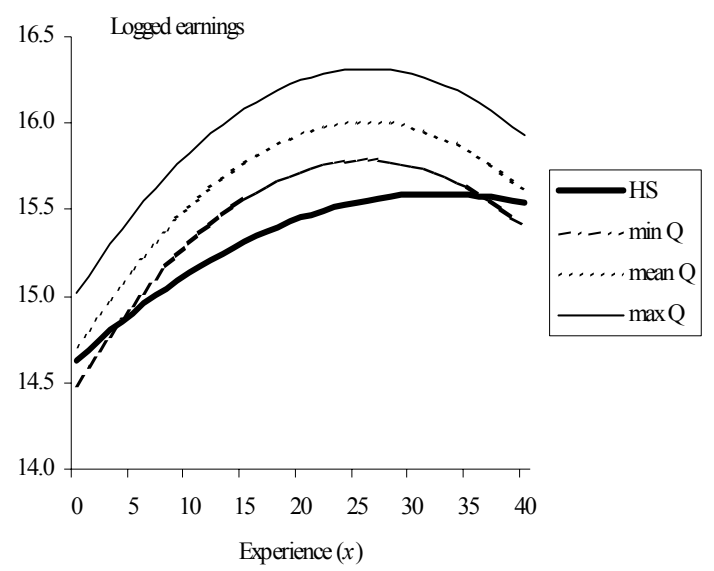

(a) Earnings profiles

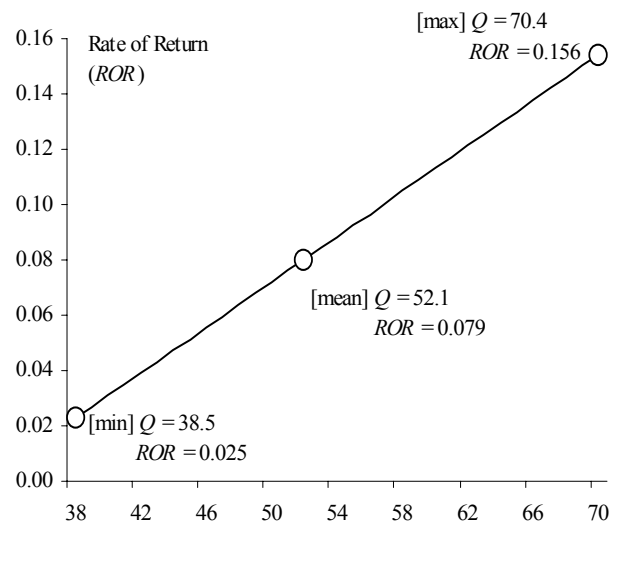

(b) Rate of return

Figure 1 Rate of return to college education as a function of college quality 